\title{
Implementation Of Legal Protection Of Children As Victims Of Domestic Psychic Violence
}

\author{
Dwi Kurniawan ${ }^{1}$
}

\begin{abstract}
This research is focused on the normative legal norms and also the object of the law as the main data, they get out of control and a book of rules, which should be fine correctness of the research that has been done. The author conducted research in the area of Semarang Polrestabes. The results of this study are: (1) Implementation of the legal protection of children as victims of domestic violence can be done in two ways, namely the vicissitudes of nonpenal and penal. Non-penal efforts undertaken by preemptive and preventive, while the penal effort is an attempt by the police as repressive as psychological violence in the domestic sphere occurred and reported to the police; (2) Constraints faced by the police in the implementation of the legal protection of children as victims of psychological violence in the household, namely: (a) Difficulty in finding strong evidence of child victims of psychological violence, in this case the question is about how to form psychological violence. (B) The difficulty to distinguish children who suffered emotional abuse committed by family members in a household setting. A child who is exposed to violence usually have a psychological fear to reveal their problems as a result of the perpetrator's actions. (C) The number of child victims of psychological violence for people who shut themselves in their environment and also included the police or Child Protective Services. (D) delay in reporting of family members in the household, Keywords: Legal Protection, Child, Domestic Violence.
\end{abstract}

\section{Introduction}

Indonesia is a country of law. In the state law states make many regulations, especially laws related to specific areas. In this paper the authors discuss the matter of children as victims of psychological violence in the household, especially on the implementation of Act No. 23 of 2004 on the Elimination of Domestic Violence (PKDRT Law), because even though the law on Elimination of Domestic Violence was created by the government but by the in fact not yet been implemented on children as victims of psychological violence in the household maximum.

The number of reports of domestic violence are increasingly encouraging authors to investigate the problem of domestic violence against children, unload the things that cause so that violence and physical impact is mainly psychological (the psychology of children) who have experienced violence or criminal acts within the scope of the household as well as the role of government and parties involved in the legal protection of children as victims of psychological violence in the household, by legal writing entitled "Implementation of Legal protection against children as victims of domestic psychic violence ".

1 Student of Masters (S2) of Law Faculty of Law Unissula Semarang email:
dwikurniawan940@gmail.com


Based on The above description of the background, then the problem can be formulated as follows: How to implement legal protection of children as victims of psychological violence in the household ?; and What constraints in the implementation of the legal protection of children as victims of psychological violence in the home?

\section{Research Methods}

The research is a normative legal research that focuses on the norms of law and legal norms assessment is done by examining the secondary data as the main data, while the primary data as a supporter.

Secondary data in this study come from: Primary and secondary law materials. Primary legal materials, ie materials that bind and positive law consists of legislation: 1) The Constitution of the Republic of Indonesia Year 1945; 2) Act No. 23 of 2002 on Child Protection; 3) Act No. 23 of 2004 on the Elimination of Domestic Violence; b) Secondary Legal Materials, the material used to provide a description of the primary legal materials and consists of literature which contains the opinions of law.

Data Collection Methods-Data was collected by means of: a. Literature studies, studies conducted by studying literature, read and understand the books, the legislation and the opinions are closely related to the material under study; b. Interviews, Interviews conducted with menga has put forward some questions to the resource directly face to face. Authors prepare questions that will be posed to the resource persons. Intervieweesis investigator Women and Children Protection Unit Polrestabes Semarang.

The data obtained from these studies were processed and analyzed by descriptive qualitative, that all the data was analyzed intact so it looks the picture of systematic and factual. Once analyzed, the authors draw conclusions using deductive thinking, that is a pattern of thinking that is based on matters of a general nature and then drawn the conclusion of a special nature.

\section{Results And Discussion}

\subsection{Overview of Legal Protection}

According to the article 8 of Act No. 39 of 1999 on Human Rights explained that the definition of protection is the defense of human rights. Every human being has the same rights and obligations. In public life often social conflicts arise that require completion and guarantees against people's behavior patterns.

Definition of protection in Article 1 of Government Regulation No. 2 of 2002 on Procedures for the Protection of Witnesses and Victims is a form of service that must be implemented by law enforcement officials or security forces to provide security, both physical and mental, to the victims and witnesses from threats, disorder, terror, and violence from any party given at the stage of investigation, investigation, prosecution and upon examination before the court. ${ }^{2}$

${ }^{2}$ R. Wijoyo 2006 Pengadilan Hak Asasi Manusia di Indonesia Penerbit Kencana Prenada Media Group Jakarta p. 78. 
According Sudikno Mertokusumo is the protection of the law is "guarantee" provided by law according to Soedikno Mertokusumo is the protection of the law is the guarantee of human rights and obligations in order to meet its own interest or in a relationship with another man. ${ }^{3}$

Child protection is all the effort that is intended to prevent, rehabilitate and empower children who experience acts of abuse, exploitation and neglect in order to ensure the survival and development of the child fairly, both physically and mentally and sosialnya.3

According to Sholeh Soeaidy SH. and Drs. Zulkhair protection of children must be based on the following strategies:

- Survival, Directed towards meeting the basic needs for survival of the child;

- Developmental, Directed towards the development of potential, inventiveness, creativity, initiative, and personal formation of the child;

- Protection, Directed at efforts to provide protection for children from different due to disorders such as, abandonment, exploitation and maltreatment;

- Participation, Geared towards giving children the opportunity to participate actively exercise its rights and obligations, through

involvement in the various activities carried out in order to develop the social welfare of children. ${ }^{4}$

\subsection{Overview of Children}

In the Article 34 of the Constitution of the Republic of Indonesia in 1945, stated the position of the child are within the discretion of article 34 which states that the poor and abandoned children reared by the state. Article 330 the Civil Code states that minors are those who have not attained the age of 21 (twenty-one) years and first mate. $^{5}$

In Act No. 4 of 1979 on Child Welfare is explicitly stipulated that the child is a person who has not attained the age of 21 years and have never been married. The age limit of 21 (twenty one) year is determined based on consideration of the child welfare business, where social maturity, personal and child mental achieved at that age. This understanding is used throughout have relevance to children in general, except for certain purposes under the laws determining the age of the other. In this case, the definition of children includes situations where a person who in his life achieving growth, need help from others (parents or adults) ${ }^{6}$.

\subsection{Overview On Psychic Violence Victims}

\subsubsection{Understanding Victims}

\footnotetext{
${ }^{3}$ Soedikno Mertokusumo 1988 Mengenal Hukum Penerbit Liberty Yogyakarta hlm. 58. ${ }^{3}$ Sholeh Soeaidy dan Zulkair 2001 Dasar Hukum Perlindungan Anak Penerbit Cv. Novindo Pustaka Mandiri Jakarta p. 4. ${ }^{4}$ Ibid. p. 5.

${ }^{5}$ Darwan Prinst 2003 Hukum Anak Indonesia Penerbit PT. Citra Aditya Bakti Bandung p. 3.

${ }^{6}$ Sholeh Soeaidy and Zulkhair Op. Cit. p. 3.
} 
Victims are they that physical and spiritual suffering as a result of the actions of others who seek the fulfillment of our own or others contrary to the interests and human suffering. ${ }^{7}$

Victims are people who either individually or collectively have suffered harm, including physical harm or mental, emotional, economic, or the substantial disruption of their rights are fundamental, through act or commission which violates the criminal law in each countries, including the abuse of power. ${ }^{8}$

There are several common rights for people who are victims in acts of violence, namely:

- The right to obtain compensation for peneritaan yangdialaminya. Compensation payment may be provided by the offender or others, such as country or special institution established to address the issue of compensation of victims of crime;

- The right to receive guidance and rehabilitation;

- The right to obtain protection from the perpetrator;

- The right to receive legal assistance;

- The right to reclaim the rights (property) of its own;

- The right to have access to medical services;

- The right to be notified when the offender will be released from provisional detention, or if the offender fugitive escape from custody;

- The right to obtain information about the police investigation relating to the crime against the victim;

- Rights of privacy, such as hide your phone number or identity of the other victims. ${ }^{9}$

\subsubsection{Understanding the Psychic Violence}

The term is used to describe the behavior of violence, with the use of force to another person. Therefore, there are four (4) types of violence, namely:

- Violence open, that is violence that can be seen as a fight;

- Violence is closed, the violence hidden or not done directly, open or closed, and whether to attack or defense, accompanied with threatening behavior;

- Aggressive violence, which is to get something like a mugging;

- Defensive violence, that violence carried out as an act of self-protection. ${ }^{10}$

Violence is the act of a person or group of people who caused the injury or death of another person or physical damage or other people's stuff. ${ }^{11}$ Indonesian Dictionary, violence is defined by the subject that is, characterized by loud, the act of someone who causes the injury or death of another person, or causing physical damage or

\footnotetext{
${ }^{7}$ Arif Gosita 2004 Masalah Korban Kejahatan Penerbit PT. Bhuana IImu Populer Kelompok Gramedia Jakarta p. 44.

${ }^{8}$ Muladi 2005 Hak Asasi Manusia Dalam Perspektif Sistem Peradilan Pidana Penerbit Refika Aditama Jakarta p. 29.

${ }^{9}$ Didik Arief Mansur dan Elisatris Gultom 2007 Urgensi Perlindungan Korban Kejahatan Penerbit Raja Grafindo Persada Jakarta p. 50.

${ }^{10}$ Thomas Santoso 2002 Teori-teori kekerasan Penerbit Ghalia Indonesia Jakarta p. 11.

${ }^{11}$ Depertement Language Center of National Education 2002 Kamus Besar Bahasa Indonesia Publisher Balai Pustaka Jakarta p. 550.
} 
goods of others, or there is no compulsion. ${ }^{12}$ According to this explanation, it is a form of violence that is more physical action causing injury, disability, pain or suffering on others. One element to consider is the form of force or the unwillingness or lack of informed consent of others injured. ${ }^{13}$

According to Yan Pramadya Puspa, violence is an act that using physical force or physical consequences that can be estimated by the parties affected by the act becomes unconscious, helpless or unable to do sesuatu.14

\section{Implementation of Legal Protection Against Children As Victims of Domestic Violence Psychic}

\subsubsection{Special protection of children as victims of psychological violence}

In Article 1 point 15 of Act No. 23 of 2002 on Child Protection declared special protection is the protection accorded to children in emergency situations, children in conflict with the law, children from minority groups and isolated, children who are economically and / or sexually, trafficked children, children who are victims of drug abuse, alcohol, psychotropic and other addictive substances (drugs), child abduction, sale, trafficking, child victims of violence either physical and / or mental, of children with disabilities, and children victims of abuse and neglect.

\subsubsection{Legal protection of children as victims of psychological violence in the household.}

Article 45 paragraph (1) of Act No. 23 of 2004 on the Elimination of Domestic Violence states that any person who commits acts of emotional violence in the domestic sphere as referred to in Article 5 letter $b$ shall be punished with imprisonment of three (3) years or a fine of not more Rp9,000,000.00 (nine million).

Article 45 paragraph (2) of the Act PKDRT stated that in terms of the act referred to in paragraph (1) committed by a husband against his wife or vice versa that does not cause disease or an obstacle to running the job position or livelihood or daily activities, shall be punished with imprisonment for a period of 4 (four) months or a maximum fine of $\operatorname{Rp~3,000,000.00~(three~million~rupiah).~}$

4.1.3. Implementation of the legal protection of children as victims of psychological violence in the household.

Based on interviews with investigators Women and Children Protection Unit Polrestabes Semarang can be seen that the legal protection of children as victims of psychological violence in the home can be done in two (2) ways, namely: Efforts NonPenal and Penal effort.

- Non-Penal effort, investigators also explainsprevention of psychological violence against children in the household can be done by means of pre-emptive and Preventive who in implementation involves various departments and agencies and Non Governmental Organization (NGO) as follows:

\footnotetext{
${ }^{12}$ H. U. Adil Samadi 2013 Kompetensi Pengadilan Agama Terhadap Kekerasan Dalam Rumah Tangga Penerbit Graha Ilmu Yogyakarta p. 29.

${ }^{13}$ Drs. Abdul Wahid dan Muhammad Irfan 2001 Perlindungan Terhadap Korban Kekerasan Seksual (Advokasi atas Hak Asasi Perempuan) Penerbit Refika Aditama Bandung p.30
} 
- preemptive, Is to do prevention early, through the activities of educative the targets affect the causal factors, the driving and the chance factor commonly referred to as a correlative factor kriminogen of the perpetrators of violence to create an awareness and vigilance and deterrence, in order terbinanya behavioral conditions and norms of life free from abuse violence against children in the family.

Forcommunities, families, or parents required policies, services, resources, and child abuse prevention training consistent and continuous. Preventive strategies include: 1) Prevention for all parents in an effort meningkatkankemampuan care and keeping of mistreatment or abuse does not occur, including child care and adequate service, work place policies that call for support, as well as life skills training for children. The meaning of life skill training includes non-violent conflict resolution, stress handling skills, resource management, make effective decisions, effective interpersonal communication, guidance or the guidance and development of the child; 2) Prevention is intended for groups of people with risikotinggi in an effort to improve parenting skills, including training and services to keep victims of abuse does not happen in the next generation.

- preventive, Namely that prevention is better than eradication. Therefore, the supervision and control by both the police and the family, the community, teachers, and religious leaders can do to prevent psychological violence in the home, by doing the following: Socialization Act No. 23 of 2003 on Child Protection and Act No. 23 of 2004 on the Elimination of Domestic Violence, especially against the parents so that parents understand that children have a set of rights which must be protected, especially by the parents themselves. Basic rights of children and for the best interests of the child. ${ }^{14}$

- Penal efforts

Penal effort is the effort made by law enforcement to protect victims of domestic psychological violence after the victim suffered psychological violence in the household.

\section{Obstacles in the Implementation of Legal Protection Against Children As Victims of Domestic Psychic Violence}

In interviews with investigators Women and Children Protection Unit (PPA) Polrestabes Semarang can be seen that the constraints faced by investigators Polrestabes Semarang in providing legal protection of children as victims of psychological violence in households in the Central Java Police, namely:

- The difficulty of finding strong evidence of a child victim of psychological violence. In this case the question is how a form of psychological violence, because the rules concerning psychological violence as stipulated in article 7, paragraph (1) of Act No. 23 of 2004 on the Elimination of Domestic Violence has not fully explain how the forms of psychological violence against children in the domestic sphere.

\footnotetext{
${ }^{14}$ Syanne Cornelia Amalia Lay 2008 Perlindungan Terhadap Anak Sebagai Korban Kekerasan Dalam Rumah Tangga p. 41.
} 
- The difficulty to distinguish children who are experiencing psychological violence committed by family members in a household setting. A child who is experiencing emotional violence usually have fear to reveal the problems experienced as a result of the act of the perpetrator.

\section{Closing}

\subsection{Conclusion}

Based on the description and analysis of the previous chapters, the authors draw conclusions in response to the problems in this study, namely:

- Implementation of the legal protection of children as victims of psychological violence in the home can be done in two (2) ways, the efforts of non-penal and penal effort. Efforts non-penal carried out by means of pre-emptive is to do prevention early, through the activities of educative the targets affect the causal factors, the driving and the chance factor commonly referred to as a correlative factor kriminogen of the perpetrators of violence to create an awareness and alertness as well as deterrence, in order terbinanya behavioral conditions and norms of life free from abuse violence against children in the family and how preventative namely that prevention is better than eradication.

- Obstacles faced by the police in the implementation of the legal protection of children as victims of psychological violence in the household is as follows:

- The difficulty of finding strong evidence of a child victim of psychological violence, in this case the question is about how a form of psychological violence.

- The difficulty to distinguish children who are experiencing psychological violence committed by family members in a household setting. A child who is experiencing emotional violence usually have fear to reveal the problems experienced as a result of the act of the perpetrator.

\subsection{Suggestion}

Based on the conclusion, suggestions are given authors are:

- Need to be socialized by law enforcement authorities to the people of Act No. 23 of 2002 on Protection of Children and Act No. 23 of 2004 on the Elimination of Domestic Violence.

- Need to do counseling and outreach to communities enumerated by the Non Governmental Organization (NGO) or a government agency about the psychological problems of children, so that parents can educate their children well and not doing psychological violence against children within the domestic sphere.

- Needs to be increased awareness of citizens to report to the authorities retrospective case series, case-psychological violence within the domestic sphere is happening in society.

- Children as victims of psychological violence within the domestic sphere bombing need in order not to shut down and open to police officers when required statement either by the police or Child Protective Services. 


\section{Bibliography}

[1] Abdul Wahid dan Muhammad Irfan 2001 Perlindungan Terhadap Korban Kekerasan Seksual (Advokasi atas Hak Asasi Perempuan) Refika Aditama Bandung.

[2] Abu Hurachan 2006 Kekerasan Terhadap Anak-anak Nuansa Bandung.

[3] Arif Gosita 2004 Masalah Korban Kejahatan PT. Bhuana IImu Populer Kelompok Gramedia Jakarta.

[4] Darwan Prinst 2003 Hukum Anak Indonesia Citra Aditya Bakti Bandung.

[5] Didik Arief Mansur dan Elisatris Gultom 2007 Urgensi Perlindungan Korban Kejahatan Raja Grafindo Persada Jakarta.

[6] H. U. Adil Samadi S. H. I. 2013 Kompetensi Pengadilan Agama Terhadap Kekerasan Dalam Rumah Tangga Graha Ilmu Yogyakarta.

[7] Maidin Gultom 2008 Perlindungan Hukum Terhadap Anak Dalam Sistem Peradilan Pidana Anak di Indonesia Refika Aditama Bandung.

[8] Maulana Hassan Wadong 2000 Advokasi dan Hukum Perlindungan Anak Grasindo PT Gramedia Widiasarana Indonesia Jakarta.

[9] MG. Endang Sumiarni dan Chandera Halim 2000 Perlindungan Hukum

[10] Terhadap Anak dalam Hukum Keluarga Universitas Atma Jaya Yogyakarta Yogyakarta.

[11] Muladi 2005 Hak Asasi Manusia Dalam Perspektif Sistem Peradilan Pidana Refika Aditama Jakarta.

[12] Pusat Bahasa Depertement Pendidikan Nasional 2002 Kamus Besar Bahasa Indonesia Balai Pustaka Jakarta.

[13] Sholeh Soeaidy dan Zulkhair 2001 Dasar Hukum Perlindungan Anak CV. Novindo Pustaka Mandiri Jakarta.

[14] Soedikno Mertokusumo 1988 Mengenal Hukum Liberty Yogyakarta.

[15] R. Wijoyo 2006 Pengadilan Hak Asasi Manusia di Indonesia Kencana Prenada Media Group Jakarta.

[16] Tim penyusun Kamus Pusat Pembinaan dan Pengembangan Bahasa 2002 Kamus Besar Bahasa Indonesia Edisi III Balai Pustaka Jakarta.

[17] Thomas Santoso 2002 Teori-teori kekerasan Ghalia Indonesia Jakarta. 